\title{
LIPID PRODUCING MICROALGAE FROM SEVERAL ECOSYSTEMS IN WEST AND CENTRAL JAVA, INDONESIA
}

\author{
DWI ANDREAS SANTOSA ${ }^{1,3^{*}}$, and SULASTRI', \\ ${ }^{1)}$ Department of Soil Science and Land Resources, Faculty of Agriculture, Bogor Agricultural University, \\ Bogor, Indonesia \\ ${ }^{2)}$ Indonesian Center for Biodiversity and Biotechnology (ICBB), Bogor, Indonesia \\ 3) SEAMEO-BIOTROP, Bogor, Indonesia
}

Received as DIPA 2008 / Accepted 17 July 2010

\begin{abstract}
This study is aimed to get lipid producing microalgae as feedstock for biofuel production. The microalgae were isolated from 355 collected water samples which represented many distinct ecosystems such as paddy fields, rivers, agricultural dams, ponds, swampy areas and unique ecosystem of volcano and mud-volcano craters in West- and Central Java, Indonesia. A total of 267 strains of microalgae were isolated from the samples of which 221 strains of them have capability to produce lipid. There were four promising strains that produce lipid between 14.7 - 45.7 percent dry weight in optimal condition that were identified as Chlamydomonas sp. KO-7267 and PK-7195, Chlorella sp. KS-7300 and Desmodesmus sp. BK-7291.
\end{abstract}

Keywords: Microalgae, lipid, biofuel, Indonesian ecosystems

\section{INTRODUCTION}

Global oil production is rapidly approaching its peak, even if natural gas liquids and expensive, destructive, and risky deepwater and polar oil are included. Based on several scenarios, the peak oil will happen sometime between 2010 - 2030 (Robert 2005). Peak oil means that half of oil reserves has been exploited and used. Peak production of oil in Indonesia has occurred in the 1990 (Full Report Workbook 2004). In 2004, Indonesia (formerly OPEC member) became a net importer. The lack of stability of future energy supplies has motivated the development of alternative energy sources in order to eliminate the possibility of a future energy shortage. Furthermore, one of the most environmental problems today is global warming, caused primarily due to the heavy use of fossil fuel. In the world, large amount of $\mathrm{CO}_{2}$

*Corresponding author : dsantosa@indo.net.id 
are released into the atmosphere. Photosynthetic microalgae are potential candidate for substitution of the fossil energy. Some strains can produce lipid which can be converted into biodiesel, while others produce petroleum like hydrocarbon. The cultivation of algae is also important to reduce the effect of climate change through utilizing excessive amount of $\mathrm{CO}_{2}$, since cultivated these organisms are capable of fixing $\mathrm{CO}_{2}$ to produce energy and chemical compounds upon exposure to sunlight. Microalgae are photosynthetic renewable resources with high lipid content, have faster growth rate than plant cells and are capable to grow in saline waters which are unsuitable for agriculture. The lipid content of microalgae on a dry cellular weight basis varies between 20 and $40 \%$. Lipid content as high as $85 \%$ has been reported for certain microalgal strains. Botryococcus braunii, is a unique microalgal strain, having a long hydrocarbon chain of between 30 and 40\% (dry weight basis) which produces almost similar compounds as crude oil. Both physical and chemical processes are applicable in the production of liquid fuels from algal strain of high lipid content. These processes include direct lipid extraction in the production of diesel oils substitutes, transesterification in the formation of ester fuels, and hydrogenation in the production of hydrocarbons (Borowitzka 1988).

Microalgae contain lipids and fatty acids as membrane components, storage products, metabolites and sources of energy. Algal fatty acids and oils have a range of potential applications. The characteristics of algal oils are similar to those of fish and vegetable oils, and can thus be considered as potential substitutes for the products of fossil oil (as a biodiesel) (Miyamoto 1997).

Cultivation of microalgae in a large scale can be considered as potential substitutes for the petroleum-based diesel used in transportation. The study conducted by NERL (National Renewable Energy Laboratory, US) found that 7.5 billion gallon of biodiesel from microalgae could be produced on 200,000 ha of desert land per year. This value equals to 214 million barrels or equivalent to $65 \%$ of total annual petroleum production in Indonesia. This value could never be reached by cultivating other energy producing plants.

Indonesian microalgae as sources of biofuel production are almost unexplored. Very few related reports and publications could be found in Indonesia. The exploration of Indonesian microalgae as a source of sustainable energy is therefore very promising.

\section{MATERIALS AND METHODS}

\section{Samples collection}

Samples were collected from rivers, lakes, paddy fields, ponds, dams, craters and saline waters in the south area of West and Central Java, and also some areas in the northern coast of coastal area of Central Java (Fig. 1). Those areas represent a large variety in soils, $\mathrm{pH}$, temperature and salinity. A number of 355 samples were collected from 36 different sites (Table 1). 


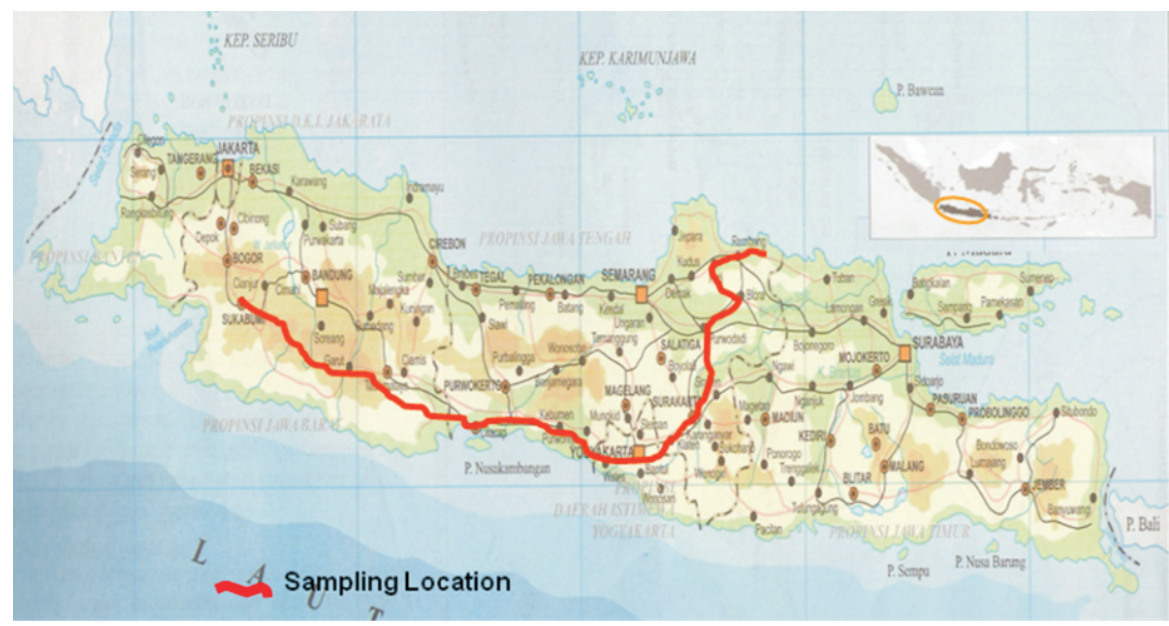

Figure 1. The sampling sites

\section{Isolation and screening of microalgae}

The soil and fresh water samples were cultured in 616 medium (ATCC) and MJ Medium (Modified Jorgensen's media for diatoms). The samples from the saline habitats were cultured in modified NORO medium (Takagi et al. 2005) containing (per litre): $\mathrm{NaCl} 29.2 \mathrm{~g} ; \mathrm{KNO}_{3} 1 \mathrm{~g} ; \mathrm{MgCl}_{2} \mathrm{H}_{2} \mathrm{O}$ 1.5g; $\mathrm{MgSO}_{4} .7 \mathrm{H}_{2} \mathrm{O} 0.5 \mathrm{~g} ; \mathrm{KCl} 0.2 \mathrm{~g} ; \mathrm{CaCl}_{2} 0.2 \mathrm{~g}$; $\mathrm{K}_{2} \mathrm{HPO}_{4} \quad 0.045 \mathrm{~g}$; tris(hydroxymethyl)aminomethane $2.45 \mathrm{~g}$; EDTA.2Na $1.8 \mathrm{~g}$; $\mathrm{ZnSO} 47 \mathrm{H} 2 \mathrm{O} 0.087 \mathrm{mg} ; \mathrm{H}_{3} \mathrm{BO}_{3} 0.61 \mathrm{mg} ; \mathrm{CoCl}_{2} \cdot 6 \mathrm{H}_{2} \mathrm{O} 0.015 \mathrm{mg} ; \mathrm{CuSO}_{4} .5 \mathrm{H}_{2} \mathrm{O} 0.06 \mathrm{mg}$; $\mathrm{MnCl}_{2} 0.23 \mathrm{mg} ; \quad\left(\mathrm{NH}_{4}\right)_{6} \mathrm{Mo}_{7} \mathrm{O}_{24} \cdot 4 \mathrm{H}_{2} \mathrm{O} 0.38 \mathrm{mg} ; \mathrm{Fe}(\mathrm{III})$ EDTA $3.64 \mathrm{mg}$. The $\mathrm{pH}$ was adjusted to 8.0 with $1 \mathrm{~N} \mathrm{HCl}$. Other culture media were used in order to obtain suitable media for their growth. The algae were subjected to purification by serial dilution followed by plating. The individual colonies were isolated and inoculated into liquid medium and incubated at $27 \pm 2{ }^{\circ} \mathrm{C}$ under $1.2 \pm 0.5$ klux light intensity with $12: 12 \mathrm{hrs}$ photoperiods. The purity of culture was ensured by repeated plating and by regular observation under microscope.

The isolates were characterized with respect to lipid and/or oil production capabilities. The lipid and oil producing microalgae were determined by using nile red (NR) staining (Qin 2005). A stock solution of NR was prepared by adding $2.5 \mathrm{mg}$ of $\mathrm{NR}$ to $100 \mathrm{ml}$ of acetone. The solution was kept in an amber-coloured bottle and stored in the dark at room temperature. The microalgae cell was stained by placing 5 $\mathrm{ml}$ of culture in a Petridish, then added with $200 \mu \mathrm{l}$ of NR stock solution to the dish. Staining of lipids and oil was completed within 30 minutes. No destaining or rinsing was required. After staining, a drop of stained cell culture was transferred to a depression slide and cover slip added. Cell culture was examined at 1000x magnification using a phase contrast microscope and epiflourescence microscope. When viewed under epiflourescent illumination, neutral lipid and oil of microalgae stained with NR will show a bright yellow/orange color (Carman1991; Qin 2005). 
The growth of microalgal culture was determined daily based on the appearance of green or brown color on the medium. The cell density was measured with a spectrophotometer using $680 \mathrm{~nm}$ wavelengths (Lee et al. 1998). The terminal optical density (OD) will mark at 0.2 , at this point the alga biomass is equivalent to $0.37 \mathrm{~g}$ of dry weight per liter (Qin 2005). The isolates were screened based on the period of time to reach OD 0.2. The total lipid production of the selected strains was measured by gravimetry methods.

\section{RESULTS AND DISCUSSIONS}

\section{Sampling}

Sample collection was conducted in West and Central Java from April 10 until April 14, 2008. Samples were taken from diverse ecosystems i.e. sampling in mountain ecosystem in West Java (Gunung Gede, Gunung Tangkuban Perahu), volcanic lakes (crater of Tangkuban Perahu, pre-historic crater of Bledug Kuwu), rivers, lakes, ponds, and rice fields in West and Central Java, as well as swampy areas in northern part of Central Java. Sampling has also been conducted in two agricultural dams i.e. Waduk Sempor, Kebumen and Waduk Kedung Ombo, Purwodadi. A number of 355 water samples have been collected from those areas. The samples and sampling location are shown in Table 1.

Table 1. Samples and sampling locations

\begin{tabular}{|c|c|c|}
\hline Code of Samples & Sampling locations & Characteristic \\
\hline CP7041-CР7050 & Ciputri, Pacet, Cianjur, West Java & $\begin{array}{l}\text { Water from paddy fields and } \\
\text { ponds }\end{array}$ \\
\hline SK7051-SK7055 & Sukamantri, Karangtengah, West Java & Water from paddy fields \\
\hline CB7056-CB7060 & Ciburung, Padalarang, West Java & Water from dam \\
\hline TP7061-ТР7080 & Tangkuban Perahu Mountain, West Java & $\begin{array}{l}\text { Water from crater, hot-sulfuric } \\
\text { water }\end{array}$ \\
\hline JL7081-JL7085 & Jaya Giri, Lembang, West Java & Water from fishponds \\
\hline PT7086-PT7090 & Highway Kopo, West Java & Water from paddy fields \\
\hline CG7091-CG7095 & Limbangan street, Garut, West Java & Water from paddy fields \\
\hline CT7095-CT7100 & Ciawi, Tasik, West Java & Water from paddy fields \\
\hline BE7101-BE7110 & Bojongsari, Cijenjing, Ciamis, West Java & Water from fishponds \\
\hline MH7111-MH7120 & Kota Banjar, West Java & Water from river \\
\hline PD7121-PD7130 & $\begin{array}{l}\text { Panulisan, Dayeuh Harja, Cilacap, Central } \\
\text { Java }\end{array}$ & Water from paddy fields \\
\hline CR7131-CR7140 & Ciraja, Kt Pucung, Cilacap, Central Java & Water from paddy fields \\
\hline JL7141-JL7145 & Jatilawang, Banyumas, Central Java & Water from paddy fields \\
\hline KJ7146-KJ7155 & $\begin{array}{l}\text { Kr.anyar, Jatilawang, Banyumas, Central } \\
\text { Java }\end{array}$ & Water from paddy fields \\
\hline TB7156-ТB7165 & $\begin{array}{l}\text { Purwodadi, Tambak, Banyumas, Central } \\
\text { Java }\end{array}$ & Water from paddy fields \\
\hline SMP7166-SMP7190 & Waduk Sempor, Kebumen, Central Java & Water from agricultural dam \\
\hline PK7191-PK7195 & $\begin{array}{l}\text { Pekunden, Kota Winangun, Kebumen, } \\
\text { Central Java }\end{array}$ & Water from paddy fields \\
\hline PR7196-PR7200 & Purworejo, DIY & Water from paddy fields \\
\hline TPK7201-ТРК7205 & Taji, Prambanan, DIY & Water from paddy fields \\
\hline MC7210-MC7225 & Metese, Ceper, Klaten, DIY & Water from paddy fields \\
\hline
\end{tabular}


Table 1. Continued

\begin{tabular}{lll}
\hline Code of Samples & \multicolumn{1}{c}{ Sampling locations } & \multicolumn{1}{c}{ Characteristic } \\
\hline PW7226-PW7235 & Pakis, Wadung Getas, Delanggu, Klaten, & Water from paddy fields \\
& DIY & \\
SG7236-SG7245 & Siwali, Gondangrejo, Central Java & Water from paddy fields \\
LS7246-LS7255 & Ngadul, Sumbu Lawang, Sragen, Central & Water from paddy fields \\
& Java & \\
KO7256-KO7275 & Waduk Kedung Ombo, Purwodadi, & Water from agricultural dam \\
& Central Java & \\
MT7276-MT7280 & Mayahan, Tawangharjo, Purwodadi, & Water from paddy fields \\
& Central Java & \\
BK7281-BK7295 & Bledug Kuwu, Grobogan, Central Java & Water from crater \\
KS7296-KS7300 & Kuwu, Grobogan, Central Java & Water from paddy fields \\
TB7301-TB7310 & Tambaksari, Blora, Central Java & Water from paddy fields \\
KSR7311-KSR7315 & Kemadu, Sulang, Rembang, Central Java & Water from paddy fields \\
BKR7316-BKR7340 & Banyudono, Kaliori, Rembang, Central & Water from fishponds, salt \\
& Java & producing ponds \\
KPR7341-KPR7350 & Karangpandan, Rembang, Central Java & Water from fishponds \\
GR7531-GR7360 & Growong, Juwana, Pati, Central Java & Water from paddy fields \\
TN7361-TN7370 & Teban, Njekulo, Kudus, Central Java & Water from paddy fields \\
TKJ7371-TKJ7380 & Tanjang, Karangjati, Central Java & Water from paddy fields \\
YW7386-YW7390 & Jogoloyo, Wono Salam, Demak & Water from paddy fields \\
KD7391-KD7395 & Pangan, Kandanghaur, Indramayu & Water from paddy fields \\
\hline
\end{tabular}

\section{Isolation and screening of Algae}

Microalgae were isolated from samples collected from rivers, lakes, brackish and freshwater ponds, paddy fields, wetland soils in West and Central Java. The method and suitable medium for the isolation of microalgae were developed during this research. The major source of microalgae isolation (155 samples) came from paddy fields. A total of 355 samples have been used for algae isolation and 267 isolates of microalgae were obtained. Some samples produced colony of algae quite fast and the medium became green after 2-3 weeks, while other samples grew slowly or did not grow. Two medium have been used i.e. Modified Jorgensen's medium and ATCC 617 medium. There were no differences between the two medium in supporting the growth of algae. The algal growth depended on the origin sample. The isolates obtained from this research were deposited at Laboratory of Soil Biotechnology of IPB and the duplicates were deposited at ICBB-Culture Collection of Micoorganisms.

\section{Distribution of microalgae based on the Origin samples}

It was shown that origin samples play important role on the success of algae isolation. Samples can be grouped into 5 : 1) paddy field, 2) river, 3) ponds, 4) agricultural dam, and 5) crater. Most samples were collected from the paddy fields. The percentage of samples from paddy fields producing colony of algae is shown in Table 2. 
Lipid producing Microalgae from several ecosystem - Dwi Andreas Santosa et al.

Table 2. The percentage and distribution of samples from paddy field that produced algal growth

\begin{tabular}{|c|c|c|c|c|c|}
\hline Sampling site & $\%$ & Sampling site & $\%$ & Sampling site & $\%$ \\
\hline \multicolumn{2}{|l|}{ West Java } & \multicolumn{4}{|c|}{ Central Java } \\
\hline Cianjur & 70 & Cilacap & 85 & Purwodadi & 80 \\
\hline Karangtengah & 60 & Banyumas & 65 & Grobogan & 80 \\
\hline Bandung & 80 & Kebumen & 45 & Blora & 90 \\
\hline Garut & 80 & Purworejo & 70 & Rembang & 80 \\
\hline Tasik & 83 & Prambanan & 80 & Pati & 63 \\
\hline \multirow[t]{3}{*}{ Indramayu } & 60 & Klaten & 70 & Kudus & 100 \\
\hline & & Karanganyar & 100 & Karangjati & 70 \\
\hline & & Sragen & 80 & Demak & 90 \\
\hline
\end{tabular}

The geographical locations of sampling showed no significant difference in algal growth. There were also no differences between samples collected from West Java and Central Java. Samples collected from four sites produced microalgae in the range of 90 - 100 percent i.e. Karanganyar, Blora, Kudus and Demak.

Microalgae are abundant and can be found not only in paddy fields but also in all of this project studied ecosystems, both man-made ecosystems such as fish ponds and agricultural dams as well as natural ecosystems. Interestingly, microalgae can also be isolated from harsh environment such as Tangkuban Perahu crater with very low $\mathrm{pH}$ (1-2) as well as Bledug Kuwu, a mud volcano crater that contains high concentration of salt. More than 60 percent of the samples, except samples collected from Padalarang Dam, produced microalgae after incubated in an appropriate media (Table 3).

Table 3. Percent growth of microalgae from different ecosystems

\begin{tabular}{lllc}
\hline \multicolumn{1}{c}{ Sampling sites } & $\%$ & \multicolumn{1}{c}{ Sampling sites } & $\%$ \\
\hline Volcano crater, Tangkuban perahu & 68 & Salt producing ponds, Rembang & 87 \\
Mud-volcano crater, Bledug Kuwu & 79 & River, Banjar & 67 \\
Dam, Padalarang & 20 & Fish pond, Lembang & 80 \\
Dam, Sempor & 64 & Fish pond, Ciamis & 60 \\
Dam, Kedung Ombo & 78 & Fish pond, Rembang & 90 \\
\hline
\end{tabular}

\section{Lipid producing microalgae}

Around 267 strains of algae could be isolated from the samples. Screening on lipid production of microalgae cell showed that 79 percent of the strains ( 212 isolates) have capability to produce lipid. Those strains are then selected for further study in order to obtain the best strain which has fast growth and high lipid production to be developed further as a source of biodiesel. Screening had been conducted on those strains and four promising isolates were selected i.e. PK-7195 produced 25.5 percent lipid, BK7291 produced 14.7 percent lipid, KO-7267 produced 35.7 percent lipid, and KS7300 produced 45.7 percent lipid under optimum condition. PK-7195 was isolated from a paddy field sample of Pekunden, Kota Winangun, Kebumen, Central Java; BK-7291 was isolated from a sample of mud-volcano crater of Bledug Kuwu, Grobogan, Central Java; KO-7267 was from Kedung Ombo Dam, Purwodadi, Central Java and KS-7300 from sample of paddy field in Kuwu, Grobogan, Central 
Java. Based on the morphological characters, isolate KO-7267 and PK-7195 are identified as Chlamydomonas sp., isolates KS-7300 identified as Chlorella sp., while BK7291 is Desmodesmus sp.

\section{ACKNOWLEDGMENT}

Authors would like to thank SEAMEO-BIOTROP for funding this research. Thanks are also due to the Dean of Faculty of Agriculture, Bogor Agricultural University for his valuable advices and help in contractual terms. Asih Karyati, Juleha, Salmah Shahab, and Hartatik are acknowledged for the laboratory works.

\section{REFERENCES}

Borowitzka M.A. 1988. In" Micro-algal Biotechnology". Eds. Borowitzka, M. A. and Borowitzka L. J., p. 257287. Cambridge University Press, Cambridge.

Carman K.R., Thistle D., Ertman S.C. and M. Foy. 1991. Nile red as a probe for lipid-storage products in benthic copepods. Marine Ecology Progress Series, 74:307-311.

Full Report Workbook. 2004. Statistical Review of World Energy. Full Report Workbook.

Lee S.J., Yoon B.D. and Oh, H.-M. 1998. Rapid methods for determination of lipid from the green Botryococcus braunii. Biotechnology Techniques, 12:553-556.

Ministry of State for Population and Environment. 1992. Indonesian Country Study on Biological Diversity. Cooperation between The United Nations Environment Programme, The Republic of Indonesia, and The Kingdom of Norway.

Miyamoto K. 1997. Renewable biological system for alternative sustainable energy production. FAO Agricultural Services Bulletin-128.

Takagi M., Karseno and T. Yoshida. 2005. Effect of salt concentration on intracellular accumulation of lipids and triacyglyceride in marine microalgae Dumaliella cell. Journal of Bioscience and Bioengineering. 101(3): 223-226.

Qin J. 2005. Bio-Hydrocarbon from Algae: Impact of temperature, light and salinity on algae growth. A Report for The Rural Industries Research and Development Corporation. Australian Government.

Robert P. 2005. The End of Oil. On the age of a Perilous New World. A Mariner Book, Boston. 